\title{
Biosorption of methylene blue from aqueous solutions by a waste biomaterial: hen feathers
}

\author{
Shamik Chowdhury $\cdot$ Papita Das Saha
}

Received: 4 February 2012/ Accepted: 29 March 2012/Published online: 24 April 2012

(C) The Author(s) 2012. This article is published with open access at Springerlink.com

\begin{abstract}
Biosorption potential of hen feathers (HFs) to remove methylene blue (MB) from aqueous solutions was investigated. Batch experiments were carried out as function of different process parameters such as $\mathrm{pH}$, initial dye concentration, biosorbent dose and temperature. The optimum conditions for removal of $\mathrm{MB}$ were found to be $\mathrm{pH}$ 7.0 , biosorbent dose $=1.0 \mathrm{~g}$, and initial dye concentration $=50 \mathrm{mg} \mathrm{L}^{-1}$. The temperature had a strong influence on the biosorption process. Experimental biosorption data were modeled by Langmuir, Freundlich and DubininRadushkevich (D-R) isotherms with the Langmuir isotherm showing the best fit at all temperatures studied. The maximum monolayer sorption capacity was determined as $134.76 \mathrm{mg} \mathrm{g}^{-1}$ at $303 \mathrm{~K}$. According to the mean free energy values of sorption $(E)$ calculated using the D-R isotherm model, biosorption of MB onto HFs was chemisorption. Kinetic studies showed that the biosorption of MB followed pseudo second-order kinetics. The activation energy $\left(E_{\mathrm{a}}\right)$ determined using the Arrhenius equation confirmed that the biosorption involved chemical ion-exchange. Thermodynamic studies showed that the biosorption process was spontaneous and exothermic. To conclude, HFs is a promising biosorbent for $\mathrm{MB}$ removal from aqueous solutions.
\end{abstract}

Keywords Biosorption - Hen feathers - Methylene blue . Equilibrium · Kinetics · Thermodynamics

S. Chowdhury $(\bowtie) \cdot$ P. D. Saha

Department of Biotechnology, National Institute of Technology, Mahatma Gandhi Avenue, Durgapur 713209, West Bengal, India e-mail: chowdhuryshamik@gmail.com

\section{Introduction}

The contamination of water bodies by synthetic dyes has created a serious environmental problem worldwide. A considerable amount of dyes is released into the aquatic ecosystems through the wastewater streams of industries such as textile, carpet, leather, paper, printing, food, cosmetics, paint, pigments, petroleum, solvent, rubber, plastic, pesticide etc. (Chowdhury et al. 2011a; Chowdhury and Saha 2010a). Dye residues affect photosynthetic activity by preventing light penetration in aquatic life and produce toxic chemicals of aromatics, metals, amines and chlorides, having a detrimental effect on flora, fauna and human beings.

Methylene blue (MB), a thiazine (cationic) dye, is commonly used for dyeing of silk, leather, plastics, paper, cotton mordanted with tannin, and also in manufacturing of paints and printing inks (Nasuha et al. 2010). It finds application in aquaculture as an alternative to malachite green for the treatment of fungal infections. In the dairy industry, it is used to determine the microbial load in the milk (Bapat et al. 2006). Although MB is not hazardous compared to other commercial dyes, acute exposure to MB can cause increased heart rate, vomiting, diarrhea, nausea and shock (Nasuha et al. 2010; ALzaydien 2009). It can cause eye burns which may lead to permanent injury to the eyes of human and animals (Rafatullah et al. 2010). On inhalation, it can give rise to short periods of rapid or difficult breathing (dyspnea), while ingestion through mouth produces a burning sensation (Rafatullah et al. 2010; Tan et al. 2008). Potential exposure to MB can also cause hypertension, pre-cordial pain, dizziness, headache, fever, fecal discoloration, profuse sweating, mental confusion, methemoglobinemia and hemolytic anemia (Saha 2009; Saha and Datta 2009; Ghosh and Bhattacharyya 2002;). Hence, there is a necessity for the treatment 
of effluents containing such dye due to its harmful impacts on receiving waters.

In recent years, biosorption has been strongly recommended as an economically viable sustainable technology for the treatment of wastewater streams (Chowdhury et al. 2011b). The importance and usefulness of biosorption in wastewater treatment is well established (Chowdhury et al. 2011b). Biosorption in environmental engineering is now an aesthetic attention and consideration in all nations, owing to its low initial cost, simplicity of design, ease of operation, insensitivity to toxic substances and complete removal of pollutants even from dilute solutions (Foo and Hameed 2010). A huge number of low-cost biosorbents based on natural materials or agro-industrial wastes such as rice husk (Saha 2009), tamarind fruit shell (Saha 2010), wheat shell (Bulut and Aydin 2006), orange peel (Annadurai et al. 2002), banana peel (Annadurai et al. 2002), pineapple leaves (Weng et al. 2009), pineapple stem (Hameed et al. 2009), peanut hull (Gong et al. 2005), garlic peel (Hameed and Ahmad 2009), rejected tea (Nasuha et al. 2010), Luffa cylindrical fibers (Demir et al. 2008), yellow passion fruit waste (Pavan et al. 2008), neem leaf powder (Bhattacharyya and Sharma 2005) etc. have been investigated intensively by researchers worldwide for the removal of MB from aqueous solutions. In recent years, researchers have focused on the application of biomaterials that are capable of biosorbing dyes from wastewaters. Biological materials such as peat, chitosan, yeast, fungi and bacterial biomass, have been used as biosorbents to concentrate and remove dyes from solutions (Srinivasan and Viraraghavan 2010). In this paper, we report the biosorption characteristics of hen feathers (HFs) - a waste biomaterial for the removal of $\mathrm{MB}$ from aqueous solution.

Feathers (chicken/hen) are generated in huge quantities as waste product at commercial poultry processing plants. Worldwide, nearly 8.5 billion tonnes of feathers are generated annually as waste by poultry-processing industries, of which India's contribution alone is 350 million tonnes (Agrahari and Wadhwa 2010). The feathers are either used as animal feed supplement in the form of feather meal, for land filling, incinerated or buried, which involves storage, handling, emission control and ash disposal problems (Taskin and Kurbanoglu 2011; Agrahari and Wadhwa 2010). Feathers are composed mainly of keratin, a kind of self organized protein with high mechanical stability (Zaghloul et al. 2011). Keratin has a high content of the amino acids glycine, alanine, serine, cysteine and valine (Taskin and Kurbanoglu 2011). These amino acids are responsible for the presence of a number of functional groups (carboxyl, hydroxyl and amine-groups) both on the backbone and the side chain of the polypeptide molecule, thereby rendering it an interesting physicochemical property for the sorption of organic/inorganic compounds
(Aguayo-Villarreal et al. 2011). Till date, few studies have proved feathers to be effective and economically feasible to remove several pollutants including dyes from aqueous solutions (Mittal et al. 2007). However, to the best of our knowledge, no study has been reported on the removal of MB using hen feathers. Thus, our primary aim was to investigate and explore the possibility of using HFs as biosorbent for the removal of $\mathrm{MB}$ from aqueous solutions. The study includes an evaluation of the effect of various operational parameters such as solution $\mathrm{pH}$, initial dye concentration, biosorbent dose and reaction temperature on the dye biosorption process with special focus on biosorption isotherms, kinetics and thermodynamics.

\section{Materials and methods}

Dye

MB (C.I. 52015, FW: 319.86, MF: $\mathrm{C}_{16} \mathrm{H}_{18} \mathrm{~N}_{3} \mathrm{SCl}$ ) used in this study was of commercial purity and used without further purification. Stock dye solution $\left(500 \mathrm{mg} \mathrm{L}^{-1}\right)$ was prepared by dissolving $0.5 \mathrm{~g}$ of the dye in $1 \mathrm{~L}$ of distilled water. Experimental dye solution of desired concentration was prepared by further dilution of the stock solution with suitable volume of distilled water. The initial solution $\mathrm{pH}$ was adjusted with $0.1 \mathrm{M} \mathrm{HCl}$ and $0.1 \mathrm{M} \mathrm{NaOH}$ solutions using a digital pH meter (LI 127, ELICO, India) calibrated with standard buffer solutions.

\section{Biosorbent}

Hen feathers used in this study were collected from a local poultry in Durgapur, West Bengal, India. The feathers were first washed with detergent and rinsed thoroughly with distilled water to remove adhering dirt and any unwanted particles. They were then washed with aqueous ethanol $(20 \% \mathrm{v} / \mathrm{v})$ to remove organic residues, and then rinsed again with distilled water. The washed feathers were then air dried and the barbs were cut into about $0.5 \mathrm{~cm}$ length with the help of scissors, discarding the hard middle rachis. Finally, the prepared biosorbent was stored in sterile, air tight glass bottles and used without any further treatment for dye biosorption.

\section{Biosorbent characterization}

Specific surface area $\left(S_{\mathrm{sp}}, \mathrm{m}^{2} \mathrm{~g}^{-1}\right)$ of the biosorbent was determined by Brunauer, Emmett, Teller (BET) method using a surface area and porosity analyzer (NOVA 2200, Quantachrome Corporations, USA). A gas mixture of $22.9 \mathrm{~mol} \%$ nitrogen and $77.1 \mathrm{~mol} \%$ helium was used for this purpose. The surface structure of the biosorbent was 
analyzed by a scanning electron microscope (S-3000 N, Hitachi, Japan) at an electron acceleration voltage of $15 \mathrm{kV}$. Prior to scanning, the biosorbent was mounted on a stainless steel stab with double stick tape and coated with a thin layer of gold in a high vacuum condition. An XRD spectrum of the biosorbent was also recorded using Miniflex X-ray diffraction spectrometer with a $\mathrm{CuK} \alpha$ radiation source (used at $30 \mathrm{kV}$ and $15 \mathrm{~mA}$, diffraction angle ranged from $60^{\circ}$ to $5^{\circ}$ with a scan speed of $5^{\circ} / \mathrm{min}$ ).

\section{Batch biosorption}

Batch mode biosorption experiments were performed in $250 \mathrm{~mL}$ glass-stoppered, Erlenmeyer flasks with $100 \mathrm{~mL}$ of dye solution of known initial concentration $\left(50 \mathrm{mg} \mathrm{L}^{-1}\right)$. A weighed amount $(1 \mathrm{~g})$ of biosorbent was added to the solution. The flasks were agitated at a constant speed of $150 \mathrm{rpm}$ for $3 \mathrm{~h}$ in an incubator shaker (Model Innova 42, New Brunswick Scientific, Canada) at $303 \pm 1 \mathrm{~K}$. The influence of $\mathrm{pH}$ (2.0-10.0), initial dye concentration (20-100 mg L $\left.\mathrm{L}^{-1}\right)$, biosorbent dose $(0.5-5 \mathrm{~g})$ and temperature (303-323 K) were evaluated during the present study. Samples were collected from the flasks at regular time intervals and the residual dye concentration in the solution was analyzed by monitoring the change in absorbance values at maximum wavelength $\left(\lambda_{\max }\right)$ of $663 \mathrm{~nm}$ using UV/Vis spectrophotometer (U-2800, Hitachi, Japan).

Control experiments were conducted in two ways: (1) without biosorbent, to check for the retention of the dye at the glassware surface and other possible losses, and (2) without the dye (in double distilled water), to verify if any colored species present in the feathers were water soluble and would contribute to the color of water, masking in the results. Dye loses at the glassware surface was negligible and no significant color effect could be accounted to the feathers.

\section{Calculations}

The amount of dye adsorbed per unit biosorbent (mg dye/g of biosorbent) was calculated according to a mass balance on the dye concentration using Eq. (1):

$q_{\mathrm{e}}=\frac{\left(C_{0}-C_{\mathrm{e}}\right) V}{m}$

where $C_{0}$ is the initial dye concentration $\left(\mathrm{mg} \mathrm{L}^{-1}\right), C_{\mathrm{e}}$ the equilibrium dye concentration in solution $\left(\mathrm{mg} \mathrm{L}^{-1}\right), V$ the volume of the solution (L), and $m$ is the mass of the biosorbent in $\mathrm{g}$. The percent removal $(\%)$ of dyes was calculated using the following equation:

Removal $(\%)=\frac{C_{0}-C_{\mathrm{e}}}{C_{0}} \times 100$.
Statistical analysis

In order to ensure the accuracy, reliability, and reproducibility of the collected data, all biosorption experiments were performed in triplicate, and the mean values were used in data analysis. Relative standard deviations were found to be within $\pm 3 \%$. Microsoft Excel 2007 program was employed for data processing.

In a biosorption study, it is necessary to fit the equilibrium biosorption data using different biosorption isotherm models and kinetic equations in order to analyze and design a biosorption process. Therefore, different theoretical models (Table 1) were applied to the experimental data. Non-linear regression analysis using Origin Pro 8.0 software was employed to determine the isotherm parameters and kinetic constants.

\section{Results and discussion}

\section{Biosorbent characterization}

The specific surface area of the biosorbent $\left(S_{\mathrm{sp}}, \mathrm{m}^{2} \mathrm{~g}^{-1}\right)$ as obtained by BET measurements was $557.9 \mathrm{~m}^{2} \mathrm{~g}^{-1}$. SEM micrograph of the biosorbent material (Fig. 1) shows a very large surface area that could possibly facilitate the entrapment and subsequent biosorption of $\mathrm{MB}$ by the surface functional groups. Figure 2 shows the diffraction pattern of HFs. Two distinct peaks are observed at $2 \theta=9.3^{\circ}$ and $19.2^{\circ}$ respectively, both indicative of semicrystalline keratin. The peak at $2 \theta=9.3^{\circ}$ can be attributed to $\alpha$-helix conformation of the protein molecule, while the peak at $2 \theta=19.2^{\circ}$ is due to the presence of stranded $\beta$-sheet structure. The results of XRD analysis are in accordance with those reported previously by AguayoVillarreal et al. 2011 for chicken feathers.

\section{Effect of $\mathrm{pH}$}

Solution $\mathrm{pH}$ is an important monitoring parameter influencing the sorption behavior of adsorbate onto biosorbent surface due to its impact on both the surface binding-sites of the biosorbent and the dye solution chemistry. In the present study, the effect of $\mathrm{pH}$ on biosorption of MB onto HFs was studied over a $\mathrm{pH}$ range of $2-10$. Results are shown in Fig. 3. The amount of dye removed at equilibrium increases with increasing $\mathrm{pH}$, appreciably up to $\mathrm{pH}$ 6.0. With further increase in $\mathrm{pH}$, there is no significant increase in the amount of dye removed. Maximum removal is observed at $\mathrm{pH}$ 7.0. Hence, all further experiments were carried out at $\mathrm{pH}$ 7.0. 
Table 1 Isotherm and kinetic models used in this study

\begin{tabular}{|c|c|c|c|}
\hline Model & Equation & Parameters & Reference \\
\hline \multicolumn{4}{|l|}{ Isotherm models } \\
\hline Langmuir & $\frac{C_{\mathrm{e}}}{q_{\mathrm{e}}}=\frac{C_{\mathrm{e}}}{q_{\mathrm{m}}}+\frac{1}{K_{\mathrm{L}} q_{\mathrm{m}}}$ & $\begin{array}{l}q_{\mathrm{e}}\left(\mathrm{mg} \mathrm{g}^{-1}\right) \text { : equilibrium sorption capacity } \\
q_{\mathrm{m}}\left(\mathrm{mg} \mathrm{g}^{-1}\right) \text { : maximum sorption capacity } \\
K_{\mathrm{L}}\left(\mathrm{L} \mathrm{mg}^{-1}\right) \text { : Langmuir constant } \\
C_{\mathrm{e}}\left(\mathrm{mg} \mathrm{L}^{-1}\right) \text { : equilibrium adsorbate concentration } \\
\text { in solution }\end{array}$ & Langmuir 1916 \\
\hline Freundlich & $\log q_{\mathrm{e}}=\log K_{\mathrm{F}}+\left(\frac{1}{n}\right) \log C_{\mathrm{e}}$ & $\begin{array}{l}K_{F}\left(\mathrm{mg} \mathrm{g}^{-1}\right)\left(\mathrm{L} \mathrm{g}^{-1}\right)^{1 / n}: \text { Freundlich constant } \\
n: \text { heterogeneity factor }\end{array}$ & Freundlich 1906 \\
\hline Dubinin-Radushkevich (D-R) & $\begin{array}{l}\ln q_{\mathrm{e}}=\ln q_{\mathrm{m}}-\beta \varepsilon^{2} \\
\varepsilon=R T \ln \left(1+\frac{1}{C_{\mathrm{e}}}\right)\end{array}$ & $\begin{array}{l}\beta\left(\mathrm{mmol}^{2} \mathrm{~J}^{-2}\right): \mathrm{D}-R \text { constant } \\
\epsilon\left(\mathrm{J} \mathrm{mmol}^{-1}\right) \text { : Polanyi potential } \\
R \text { : universal gas constant }\left(8.314 \mathrm{~J} \mathrm{~mol}^{-1} \mathrm{~K}^{-1}\right) \\
T(\mathrm{~K}) \text { : temperature }\end{array}$ & $\begin{array}{l}\text { Dubinin and } \\
\text { Radushkevich } 1947\end{array}$ \\
\hline \multicolumn{4}{|l|}{ Kinetic models } \\
\hline Pseudo-first order & $\log \left(q_{\mathrm{e}}-q_{\mathrm{t}}\right)=\log q_{\mathrm{e}}-\frac{k_{1}}{2.303} t$ & $\begin{array}{l}q_{\mathrm{t}}\left(\mathrm{mg} \mathrm{g}^{-1}\right) \text { : amount of adsorbate adsorbed } \\
\text { at time } t \\
k_{1}\left(\min ^{-1}\right) \text { : pseudo-first-order rate constant }\end{array}$ & Lagergren 1898 \\
\hline Pseudo-second order & $\frac{t}{q_{\mathrm{t}}}=\frac{1}{k_{2} q_{\mathrm{e}}^{2}}+\frac{1}{q_{\mathrm{e}}} t$ & $\begin{array}{l}k_{2}\left(\mathrm{~g} \mathrm{mg}^{-1} \min ^{-1}\right): \text { pseudo-second-order } \\
\text { rate constant }\end{array}$ & Blanchard et al. 1984 \\
\hline
\end{tabular}

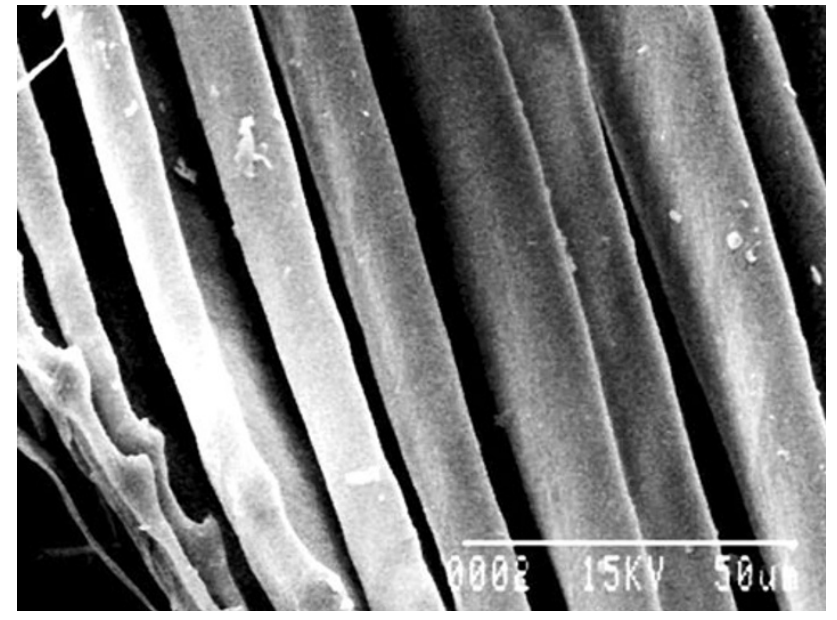

Fig. 1 SEM micrograph of HF (magnification: 1,000×)

The $\mathrm{pH}$ of the aqueous solution affects both the surface charge of the biosorbent material as well as the degree of ionization of the dye molecule. Feathers mainly contain $\mathrm{N}-\mathrm{H}, \mathrm{C}=\mathrm{O}$ and $\mathrm{C}-\mathrm{H}$ functional groups on their surface (Aguayo-Villarreal et al. 2011). Protonation of these functional groups at low $\mathrm{pH}$ values renders a net negative charge to the biosorbent surface while deprotonation of the functional groups at high $\mathrm{pH}$ values render it positively charged. The $\mathrm{pK}_{\mathrm{a}}$ of MB is 0.04 (Weng et al. 2009); hence, it is completely ionized at $\mathrm{pH}>0.04$ and exists as cationic species. At low $\mathrm{pH}$ values, there exists a strong electronegative repulsion between the positively charged dye ions and the negatively charged HF surface resulting in low dye

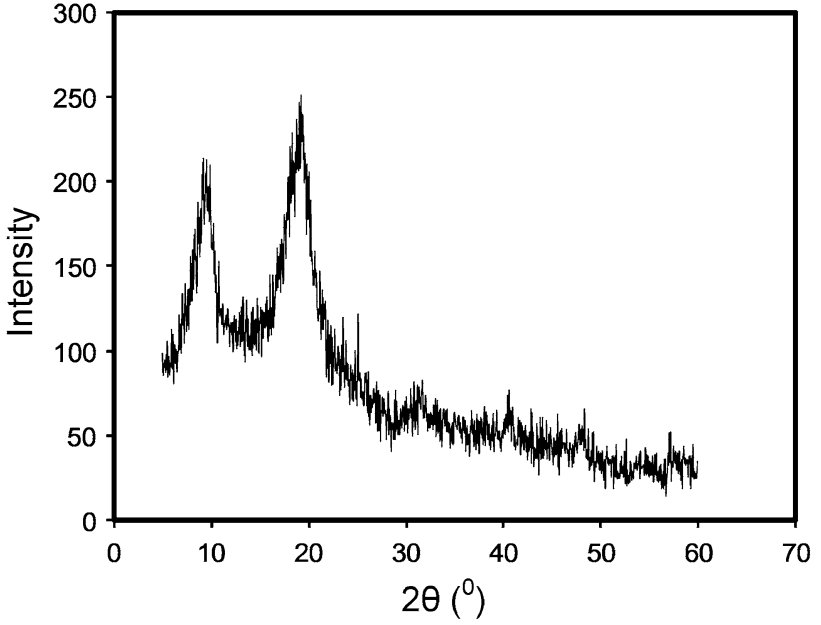

Fig. 2 XRD spectrum of HF

uptake capacity. On the contrary, as the $\mathrm{pH}$ of the dye solution increases, a considerable increase in adsorptive removal of dye is observed due to strong electrostatic attraction between negatively charged sites on the biosorbent and the dye cations. Similar results were previously reported for biosorption of MB from aqueous solution onto garlic peel (Hameed and Ahmad 2009), neem leaf powder (Bhattacharyya and Sharma 2005) and yellow passion fruit peel (Pavan et al. 2008).

\section{Effect of biosorbent dose}

Biosorbent dose is an important parameter influencing the biosorption process since it determines the biosorption 


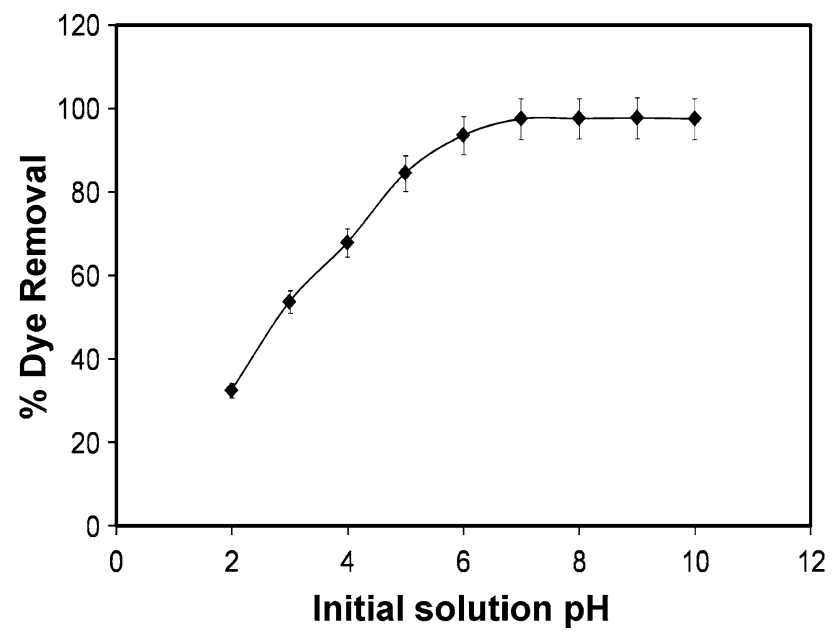

Fig. 3 Effect of $\mathrm{pH}$ on biosorption of $\mathrm{MB}$ by HFs (experimental conditions: initial $\mathrm{MB}$ concentration $=50 \mathrm{mg} \mathrm{L}^{-1}$, biosorbent dose $=$ $1 \mathrm{~g} / 0.1 \mathrm{~L}^{-1}, \quad$ agitation speed $=150 \mathrm{rpm}, \quad$ contact time $=3 \mathrm{~h}$, temp. $=303 \mathrm{~K}$, error bars represent the standard deviation at $n=3$ )

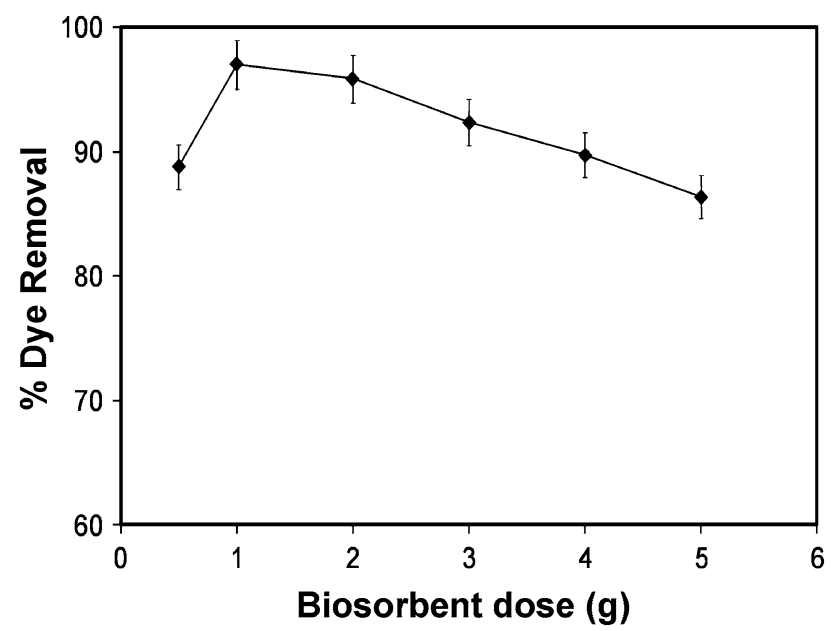

Fig. 4 Effect of biosorbent dose on biosorption of MB by HFs (experimental conditions: initial $\mathrm{MB}$ concentration $=50 \mathrm{mg} \mathrm{L}^{-1}, \mathrm{pH}$ 7.0 , agitation speed $=150 \mathrm{rpm}$, contact time $=3 \mathrm{~h}$, temp. $=303 \mathrm{~K}$, error bars represent the standard deviation at $n=3$ )

capacity of a biosorbent for a given initial concentration of the adsorbate under the operating conditions. Therefore, the effect of biosorbent dose on biosorption of MB by HFs was investigated. The amount of biosorbent was varied from 0.50 to $5.00 \mathrm{~g}$ in $100 \mathrm{~mL}$ dye solution, while all the other variables such as $\mathrm{pH}$, agitation speed, contact time, and temperature were kept constant. Data obtained from the experiments are presented in Fig. 4. With increase in biosorbent dose from 0.5 to $1 \mathrm{~g}$, the dye removal efficiency increases from 85.76 to $97.02 \%$, which is probably due to an increase in the number of binding sites available for biosorption (Saeed et al. 2010; Ahmad 2009). Further increase in biosorbent dose reduces the percentage removal

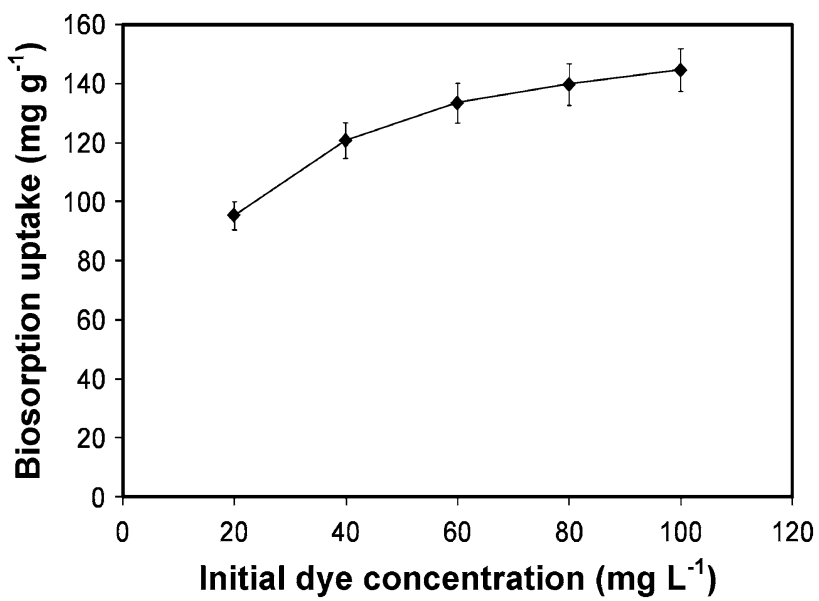

Fig. 5 Effect of initial dye concentration on biosorption of MB by HFs (experimental conditions: $\mathrm{pH}$ 7.0, biosorbent dose $=1 \mathrm{~g} / 0.1 \mathrm{~L}^{-1}$, agitation speed $=150 \mathrm{rpm}$, contact time $=3 \mathrm{~h}$, temp. $=303 \mathrm{~K}$, error bars represent the standard deviation at $n=3$ )

of MB. Such behavior can be attributed to saturation of the dye binding sites due to particulate interaction such as aggregation (Aksakal and Ucun 2010). Therefore, in the following experiments, the biosorbent dose was fixed at $1 \mathrm{~g}$. These observations are in agreement with those reported previously by other researchers for the sorption of dyes by different sorbent materials (Aksakal and Ucun 2010; Crini et al. 2007).

\section{Effect of initial dye concentration}

Biosorption of MB onto HFs was also carried out at different initial dye concentrations $(20,40,60,80$, and $100 \mathrm{mg} \mathrm{L}^{-1}$ ) and the results are shown in Fig. 5. It is clearly evident from the figure that the biosorption capacity increases with increasing initial dye concentration. Initial dye concentration provides an important driving force to overcome all mass transfer resistances of all molecules between the aqueous and solid phases (Chowdhury and Saha 2010a). Hence, a higher initial dye concentration of dye will enhance the biosorption process. A similar trend has been reported by Yao et al. (2009) for biosorption of MB by Xanthoceras sorbifolia seed coat.

\section{Effect of temperature}

Temperature has pronounced effect on the sorption removal of dyes from aqueous solutions. As such, the effect of temperature on the biosorption process of MB was studied in the range of $303-323 \mathrm{~K}$ and the results are depicted in Fig. 6. The figure shows that the dye uptake capacity decreases with increasing temperature. This finding suggests that MB uptake process was exothermic in nature. The negative correlation between temperature and 
dye biosorption capacity may be due to the weakening of bonds between the dye molecules and the active site of the biosorbent (Chowdhury and Saha 2010a). Also with increasing temperature, the solubility of $\mathrm{MB}$ increases. Consequently, the interaction forces between the solute and the solvent are stronger than those between the solute and the biosorbent. As a result, the solute is more difficult to adsorb (Chowdhury and Saha 2010a). Similar findings have been reported for biosorption of MB by Brazil nut shells (de Oliveira Brito et al. 2010) and Ulothrix sp. (Dogar et al. 2010).

\section{Biosorption isotherms}

The analysis of a biosorption process depends on the equilibrium relationship between the adsorbate concentration in the liquid phase and that on the biosorbent's surface at a given condition, called an isotherm. An isotherm is a thermodynamic basis of a biosorption separation processes and determines the extent to which a material can be adsorbed onto a particular surface (Chowdhury et al. 2011c). A variety of isotherms have been developed to describe equilibrium relationships. However, no single model is universally

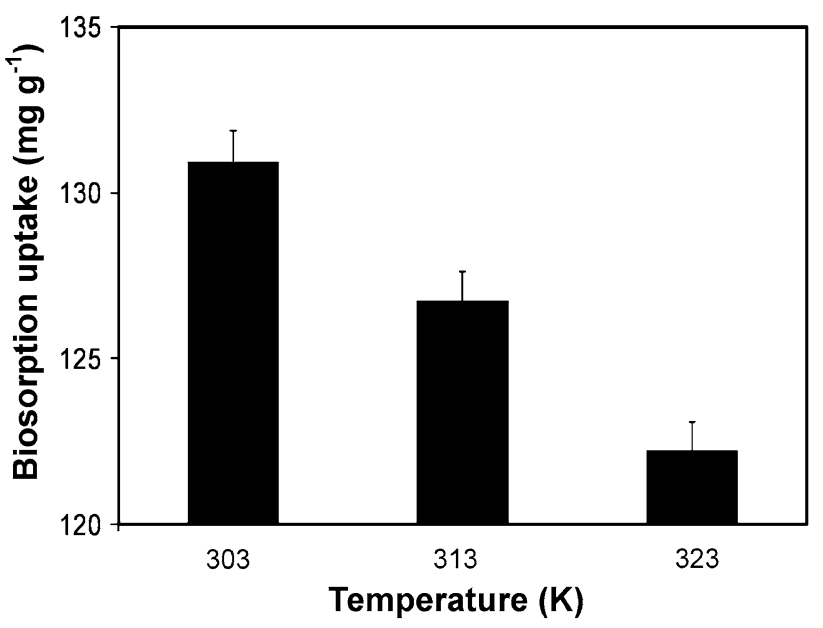

Fig. 6 Effect of temperature on biosorption of MB by HFs (exper-

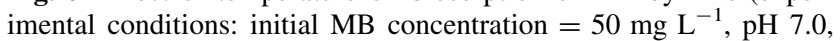
biosorbent dose $=1 \mathrm{~g} / 0.1 \mathrm{~L}^{-1}$, agitation speed $=150 \mathrm{rpm}$, contact time $=3 \mathrm{~h}$, error bars represent the standard deviation at $n=3$ ) applicable; all involve assumptions which may or may not be valid in particular cases. In the present study, the two parameter isotherms of Freundlich, Langmuir and DubininRadushkevich (D-R) were employed to study the biosorption process of MB onto HFs (Table 1).

The Langmuir, Freundlich and D-R isotherm model parameters determined using non-linear regression analysis are summarized in Table 2. To quantitatively compare the accuracy of the models, the correlation coefficients $\left(R^{2}\right)$ were also calculated and are also listed in Table 2. According to the $R^{2}$ values in Table 2, the Langmuir isotherm model shows best fit to the equilibrium MB biosorption data than the other isotherm models at all studied temperatures (Fig. 7). The suitability of the Langmuir isotherm model suggests monolayer coverage of dye molecules on the biosorbent surface. The maximum MB biosorption capacity of HFs is $134.76 \mathrm{mg} \mathrm{g}^{-1}$ at $303 \mathrm{~K}$. The value of the Freundlich constant $n$ is significantly higher than unity at all the temperatures studied indicating that the MB biosorption behavior of HFs can be considered as favorable (Chowdhury et al. 2011b).

The $\mathrm{D}-\mathrm{R}$ isotherm model constant $\beta$ gives an idea about the mean free energy $E\left(\mathrm{~kJ} \mathrm{~mol}^{-1}\right)$ of sorption per mole of the adsorbate which in turn can give information about the type of sorption mechanism. $E$ can be calculated using the relationship (Chakraborty et al. 2011):

$E=\frac{1}{\sqrt{2 \beta}}$

If the magnitude of $E$ is between 8 and $16 \mathrm{~kJ} \mathrm{~mol}^{-1}$, the biosorption process is supposed to proceed via chemisorption, while for values of $E<8 \mathrm{~kJ} \mathrm{~mol}^{-1}$, the sorption process is of physical nature (Chakraborty et al. 2011). The estimated values of $E$ for the present study were found to be $>8 \mathrm{~kJ} \mathrm{~mol}^{-1}$ at all temperatures studied (Table 2) implying that the biosorption mechanism of $\mathrm{MB}$ on HFs involves chemical ion-exchange.

\section{Biosorption kinetics}

Biosorption kinetics is expressed as the solute removal rate, which in turn controls the residence time of the sorbate in

Table 2 Isotherm constants for biosorption of MB by HFs

\begin{tabular}{|c|c|c|c|c|c|c|c|c|c|c|}
\hline \multirow[t]{2}{*}{$T(\mathrm{~K})$} & \multicolumn{3}{|l|}{ Langmuir } & \multicolumn{3}{|l|}{ Freundlich } & \multicolumn{4}{|c|}{ Dubinin-Radushkevich } \\
\hline & $\begin{array}{l}q_{\mathrm{m}} \\
\left(\mathrm{mg} \mathrm{g}^{-1}\right)\end{array}$ & $\begin{array}{l}K_{\mathrm{L}} \\
\left(\mathrm{L} \mathrm{mg}^{-1}\right)\end{array}$ & $R^{2}$ & $\begin{array}{l}K_{\mathrm{F}} \\
\left(\mathrm{mg} \mathrm{g}^{-1}\right) \\
\left(\mathrm{L} \mathrm{mg}^{-1}\right)^{1 / n}\end{array}$ & $n$ & $R^{2}$ & $\begin{array}{l}q_{\mathrm{m}} \\
\left(\mathrm{mg} \mathrm{g}^{-1}\right)\end{array}$ & $\begin{array}{l}\beta \\
\left(\mathrm{mmol}^{2} \mathrm{~J}^{-2}\right)\end{array}$ & $E\left(\mathrm{~kJ} \mathrm{~mol}^{-1}\right)$ & $R^{2}$ \\
\hline 303 & 134.76 & 3.67 & 0.994 & 82.85 & 7.49 & 0.967 & 97.33 & $2.04 \times 10^{-9}$ & 15.67 & 0.912 \\
\hline 313 & 130.34 & 3.19 & 0.991 & 75.27 & 6.77 & 0.954 & 92.45 & $2.48 \times 10^{-9}$ & 14.21 & 0.906 \\
\hline 323 & 127.09 & 2.71 & 0.987 & 69.96 & 6.28 & 0.952 & 88.81 & $2.73 \times 10^{-9}$ & 13.52 & 0.892 \\
\hline
\end{tabular}


the solid-solution interface. In addition, information on the kinetics of solute uptake rate is also required to select the optimum condition for full-scale batch sorption processes. Several sorption kinetic models have been established to describe the reaction order of sorption systems based on solution concentration. These include pseudo-first-order model, pseudo-second-order model, Weber and Morris sorption kinetic model, first-order reversible reaction model, external mass transfer model, first-order equation of Bhattacharya and Venkobachar, Elovich's model and Ritchies's equation (Chowdhury and Saha 2010b). However, the pseudo-first-order and pseudo-second-order kinetic models are the most well-liked model to study the sorption kinetics of dyes and have been widely used in the kinetic study of dye sorption using various kinds of sorbent materials (Chowdhury and Saha 2010b). By acknowledging their wide application and usefulness in sorption studies, the pseudo-first-order and pseudo-second-order kinetic models (Table 1) were used to study the kinetics of MB biosorption onto HFs in the present study.

The pseudo-first-order and pseudo-second-order rate constants $\left(k_{1}, k_{2}, q_{\mathrm{e}}\right)$ determined using non-linear regression analysis along with the corresponding $R^{2}$ values are listed in Table 3. As can be seen from Table 3, the low $R^{2}$

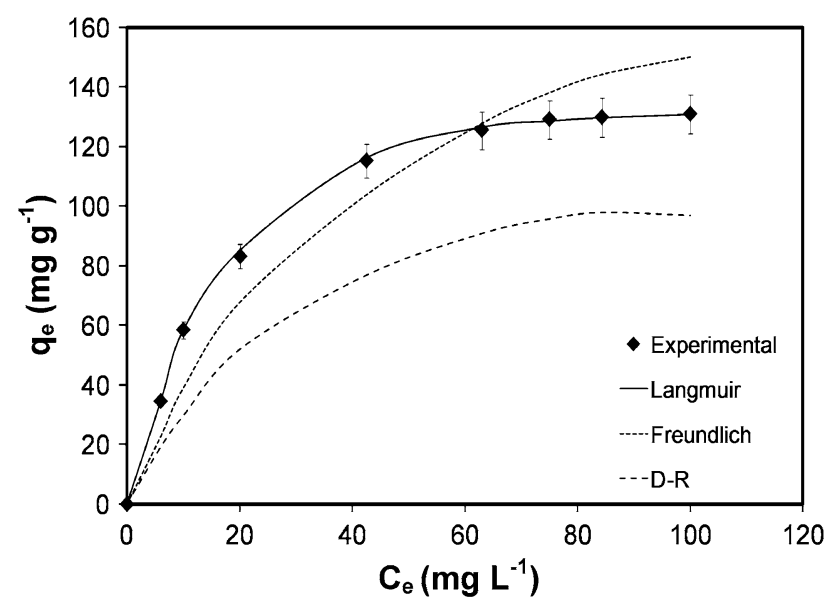

Fig. 7 Comparison between the measured and modeled isotherm profiles for biosorption of MB by HFs (experimental conditions: initial $\mathrm{MB}$ concentration $=50 \mathrm{mg} \mathrm{L}^{-1}, \mathrm{pH} 7.0$, biosorbent dose $=$ $1 \mathrm{~g} / 0.1 \mathrm{~L}^{-1}$, agitation speed $=150 \mathrm{rpm}, \quad$ contact time $=3 \mathrm{~h}$, temp. $=303 \mathrm{~K}$, error bars represent the standard deviation at $n=3$ )
$(<0.90)$ values for the pseudo-first-order model indicate that this model was not suitable for describing the biosorption kinetics of MB. However, the relatively high $R^{2}$ $(>0.99)$ values for the pseudo-second-order model suggest that the ongoing biosorption process obeys pseudo-secondorder kinetics at all studied temperatures. Also, as can be seen in Table 3 , the calculated $q_{\mathrm{e}}$ values $\left(q_{\mathrm{e}, \mathrm{cal}}\right)$ show good agreement with the experimental $q_{\mathrm{e}}$ values ( $\left.q_{\mathrm{e} \text {,exp}}\right)$, confirming that the biosorption of MB onto HFs follows the pseudo-second-order kinetic model. A comparison of the pseudo-second-order model with the experimental kinetic data is illustrated in Fig. 8. The applicability of the pseudosecond-order kinetic model indicates that the biosorption process of MB onto HFs is chemisorption and the ratedetermining step is probably surface sorption. Similar phenomena have been observed for biosorption of MB by pineapple leaf powder (Weng et al. 2009) and rejected tea (Nasuha et al. 2010).

\section{Activation energy}

The activation energy $\left(E_{\mathrm{a}}\right)$ for biosorption of MB by HFs was determined using the Arrhenius equation (Chowdhury and Saha 2010a):

$\ln k=\ln A-\frac{E_{\mathrm{a}}}{R T}$

where $k$ is the rate constant, $A$ the Arrhenius constant, $E_{\mathrm{a}}$ the activation energy $\left(\mathrm{kJ} \mathrm{mol}^{-1}\right), R$ the gas constant (8.314 $\mathrm{J} \mathrm{mol}^{-1} \mathrm{~K}^{-1}$ ) and $T$ is the temperature $(\mathrm{K})$. The value of $E_{\mathrm{a}}$ for biosorption of $\mathrm{MB}$ by HFs, as estimated from the slope of the linear plot of $\ln k_{2}$ versus $1 / T$, was $72.79 \mathrm{~kJ} \mathrm{~mol}^{-1}$. The magnitude of $E_{\mathrm{a}}$ gives information on the nature of the sorption process, i.e., whether it is physical or chemical, with the values of $E_{\mathrm{a}}<40 \mathrm{~kJ} \mathrm{~mol}^{-1}$ corresponds to physisorption and higher values represent chemical reaction process (Chowdhury and Saha 2010a). As such it can be said that the biosorption process of $\mathrm{MB}$ onto HFs is chemisorption.

The Eyring equation was used to calculate the standard enthalpy $\left(\Delta H^{\#}\right)$, and entropy of activation $\left(\Delta S^{\#}\right)$ (Chowdhury et al. 2011a):

$\ln \frac{k}{T}=\ln \frac{k_{\mathrm{B}}}{h}+\frac{\Delta S^{\#}}{R}-\frac{\Delta H^{\#}}{R T}$

Table 3 Kinetic parameters for biosorption of MB by HFs

\begin{tabular}{|c|c|c|c|c|c|c|c|}
\hline \multirow[t]{2}{*}{$T(\mathrm{~K})$} & \multirow[t]{2}{*}{$q_{\mathrm{e}, \exp }\left(\mathrm{mg} \mathrm{g}^{-1}\right)$} & \multicolumn{3}{|c|}{ Pseudo-first order } & \multicolumn{3}{|c|}{ Pseudo-second order } \\
\hline & & $q_{\mathrm{e}, \mathrm{cal}}\left(\mathrm{mg} \mathrm{g}^{-1}\right)$ & $k_{1}\left(\min ^{-1}\right)$ & $R^{2}$ & $q_{\mathrm{e}, \mathrm{cal}}\left(\mathrm{mg} \mathrm{g}^{-1}\right)$ & $k_{2}\left(\mathrm{~g} \mathrm{mg}^{-1} \mathrm{~min}^{-1}\right)$ & $R^{2}$ \\
\hline 303 & 130.94 & 85.37 & $6.81 \times 10^{-2}$ & 0.892 & 131.52 & $4.54 \times 10^{-3}$ & 0.99 \\
\hline 313 & 126.75 & 82.18 & $5.47 \times 10^{-2}$ & 0.883 & 127.38 & $2.12 \times 10^{-3}$ & 0.999 \\
\hline 323 & 122.23 & 78.59 & $4.62 \times 10^{-2}$ & 0.895 & 123.04 & $7.56 \times 10^{-4}$ & 0.997 \\
\hline
\end{tabular}




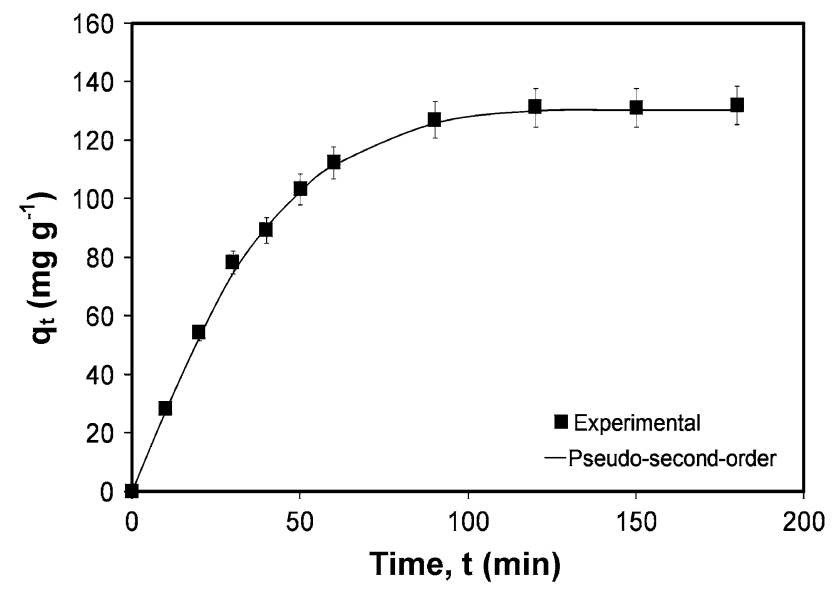

Fig. 8 Pseudo-second-order kinetics for biosorption of MB by HFs (experimental conditions: initial MB concentration $=50 \mathrm{mg} \mathrm{L}^{-1}, \mathrm{pH}$ 7.0, biosorbent dose $=1 \mathrm{~g} / 0.1 \mathrm{~L}^{-1}$, agitation speed $=150 \mathrm{rpm}$, contact time $=3 \mathrm{~h}$, temp. $=303 \mathrm{~K}$, error bars represent the standard deviation at $n=3$ )

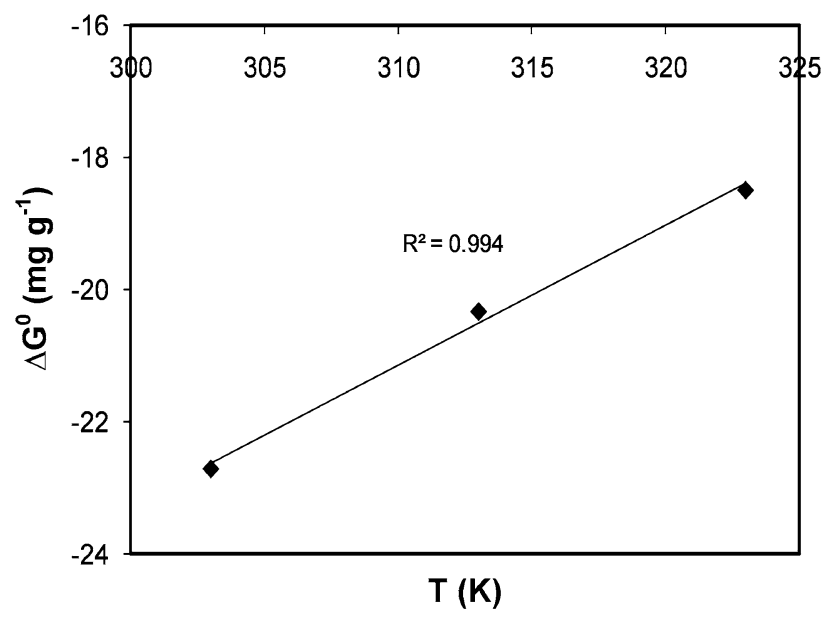

Fig. 9 Plots of Gibb's free energy change versus temperature for biosorption of MB by HFs

where $k$ is the rate constant, $k_{\mathrm{B}}$ the Boltzman constant $\left(1.3807 \times 10^{-23} \mathrm{~J} \mathrm{~K}^{-1}\right), h$ the Plank constant $(6.6261 \times$ $\left.10^{-34} \mathrm{~J} \mathrm{~s}\right), R$ the gas constant $\left(8.314 \mathrm{~J} \mathrm{~mol}^{-1} \mathrm{~K}^{-1}\right)$ and $T$ is the temperature $(\mathrm{K})$. The values of $\Delta H^{\#}$ and $\Delta S^{\#}$ were calculated from the slope and intercept of the plot of $\ln \left(k_{2} / T\right)$ versus $1 / T$ and were found to be $-75.38 \mathrm{~kJ}$ $\mathrm{mol}^{-1}$ for $\Delta H^{\#}$ and $-143.61 \mathrm{~J} \mathrm{~mol}^{-1} \mathrm{~K}^{-1}$ for $\Delta S^{\#}$. The negative value of $\Delta H^{\#}$ indicates exothermic nature of the biosorption process. The negative value of $\Delta S^{\#}$ suggests that biosorption of MB onto HFs is an associative mechanism (Chowdhury et al. 2011a).

The values of $\Delta H^{\#}$ and $\Delta S^{\#}$ were used to compute the free energy of activation $\left(\Delta G^{\#}\right)$ from the relation:

$\Delta G^{\#}=\Delta H^{\#}-T \Delta S^{\#}$
The values of $\Delta G^{\#}$ were found to be $-31.86,-30.43$, and $-28.99 \mathrm{~kJ} \mathrm{~mol}^{-1}$ at $T=303,313$, and $323 \mathrm{~K}$, respectively. The negative values of $\Delta G^{\#}$ suggest that the energy was released in the biosorption reaction to convert reactants into products.

Biosorption thermodynamics

Thermodynamic consideration of a biosorption process is necessary to conclude whether the process is spontaneous or not. The Gibbs free energy change $\left(\Delta G^{\circ}\right)$ is a critical factor for determining the spontaneity of a process and can be computed by the classical Van't Hoff equation (Chowdhury and Saha 2010a):

$\Delta G^{\circ}=-R T \ln K_{\mathrm{C}}$

where $R$ is the universal gas constant $\left(8.314 \mathrm{~J} \mathrm{~mol}^{-1} \mathrm{~K}^{-1}\right)$, $T$ is the absolute temperature $(\mathrm{K})$ and $K_{\mathrm{C}}$ is the distribution coefficient for biosorption defined as:

$K_{\mathrm{C}}=\frac{C_{\mathrm{a}}}{C_{\mathrm{e}}}$

in which $C_{\mathrm{a}}$ is the equilibrium adsorbate concentration on the biosorbent $\left(\mathrm{mg} \mathrm{L}^{-1}\right)$ and $C_{\mathrm{e}}$ is the equilibrium adsorbate concentration in solution $\left(\mathrm{mg} \mathrm{L}^{-1}\right)$.

It is also known that $\Delta G^{\circ}$ is a function of change in enthalpy $\left(\Delta H^{\circ}, \mathrm{kJ} \mathrm{mol}^{-1}\right)$ as well as change in standard entropy $\left(\Delta S^{\circ}, \mathrm{J} \mathrm{mol}^{-1} \mathrm{~K}^{-1}\right)$ according to the following equation:

$\Delta G^{\circ}=\Delta H^{\circ}-T \Delta S^{\circ}$

The values of $\Delta G^{\circ}$ were estimated to be $-22.71,-20.33$ and $-18.49 \mathrm{~kJ} \mathrm{~mol}^{-1}$ at $T=303,313$ and $323 \mathrm{~K}$, respectively. The negative value of $\Delta G^{\circ}$ at different temperatures indicates spontaneous nature of the biosorption process. Furthermore, decrease in the negative value of $\Delta G^{\circ}$ with increasing temperature suggests that the biosorption process was more favorable at lower temperatures. $\Delta H^{\circ}$ and $\Delta S^{\circ}$ were determined from the intercept and slope of the plot of $\Delta G^{\circ}$ versus $T$ (Fig. 9). The value of $\Delta H^{\circ}$ was calculated as $-86.55 \mathrm{~kJ} \mathrm{~mol}^{-1}$, and $-1.75 \mathrm{~kJ} \mathrm{~mol}^{-1} \mathrm{~K}^{-1}$ for $\Delta S^{\circ}$. The negative value of $\Delta H^{\circ}$ is indicative of the fact that the biosorption reaction was exothermic. The negative value of $\Delta S^{\circ}$ suggests that the process is enthalpy driven.

Comparison of HFs with other sorbents

A comparative study of the maximum dye uptake capacity of HFs has been carried out with other reported sorbents. The maximum amount of MB uptake by HFs has been compared to the maximum MB uptake capacity of other reported sorbents and is presented in Table 4. From 
Table 4 Comparison of MB sorption capacity of HFs with other reported low-cost sorbent materials

\begin{tabular}{|c|c|c|}
\hline Sorbent & $\begin{array}{l}\text { Maximum sorption } \\
\text { capacity }\left(\mathrm{mg} \mathrm{g}^{-1}\right)\end{array}$ & Reference \\
\hline Hen feathers & 134.76 & This study \\
\hline Meranti sawdust & 120.48 & Ahmad et al. (2009) \\
\hline Pineapple stem & 119.05 & Hameed et al. (2009) \\
\hline $\begin{array}{l}\text { Dehydrated } \\
\text { peanut hull }\end{array}$ & 108.6 & Ozer et al. (2007) \\
\hline Coconut husk & 99 & Low and Lee (1990) \\
\hline Coffee husk & 90.1 & Oliveira et al. (2008) \\
\hline Garlic peel & 82.64 & $\begin{array}{l}\text { Hameed and Ahmad } \\
\text { (2009) }\end{array}$ \\
\hline Rubber seed shell & 82.64 & Oladoja et al. (2008) \\
\hline $\begin{array}{l}\text { Fallen phoenix tree's } \\
\text { leaves }\end{array}$ & 80.9 & Han et al. (2007) \\
\hline Ground hazelnut shells & 76.9 & Ferrero (2007) \\
\hline Peanut hull & 68.03 & Gong et al. (2005) \\
\hline Walnut sawdust & 59.17 & Ferrero (2007) \\
\hline Luffa cylindrical fibers & 47 & Demir et al. (2008) \\
\hline $\begin{array}{l}\text { Yellow passion fruit } \\
\text { waste }\end{array}$ & 44.70 & Pavan et al. (2008) \\
\hline Olive pomace & 42.3 & Banat et al. (2007) \\
\hline Rice husk & 40.59 & $\begin{array}{l}\text { Vadivelan and Kumar } \\
\text { (2005) }\end{array}$ \\
\hline Cherry sawdust & 39.84 & Ferrero (2007) \\
\hline Banana peel & 20.8 & Annadurai et al. (2002) \\
\hline Orange peel & 18.6 & Annadurai et al. (2002) \\
\hline Wheat shells & 16.56 & Bulut and Aydin (2006) \\
\hline Egg shell & 16.43 & Sharma et al. (2009) \\
\hline Coconut coir & 15.59 & Tsai et al. (2006) \\
\hline $\begin{array}{l}\text { Indian rosewood } \\
\text { sawdust }\end{array}$ & 11.8 & Garg et al. (2004) \\
\hline Neem leaf powder & 3.67 & $\begin{array}{l}\text { Bhattacharyya and } \\
\text { Sharma (2005) }\end{array}$ \\
\hline Fly ash & 1.91 & Saha and Datta (2009) \\
\hline Tamarind fruit shell & 1.72 & Saha (2010) \\
\hline
\end{tabular}

Table 4 it is evident that the maximum sorption capacity of HFs for MB is comparable and moderately higher than that of many corresponding sorbent materials. Differences in dye uptake capacity are due to the differences in properties of each sorbent material such as structure, functional groups and surface area. The easy availability and cost effectiveness of HFs are some additional advantages, which make it better biosorbent for the removal of MB from aqueous solutions.

\section{Conclusion}

In this study, the efficacy of HFs as biosorbent for removal of MB from aqueous solutions was investigated. Batch mode biosorption studies indicate that the biosorption was strongly dependent on solution $\mathrm{pH}$, initial dye concentration, biosorbent dose and reaction temperature. The equilibrium biosorption data obtained at different temperatures fitted well in the Langmuir isotherm model indicating monolayer biosorption on a homogeneous surface. The maximum monolayer biosorption capacity was found to be $134.76 \mathrm{mg} \mathrm{g}^{-1}$ at $303 \mathrm{~K}$ which is considerably higher than that of many other sorbent materials reported in the literature. The mean free energy $(E)$ calculated from the D-R isotherm model as well as the activation energy $\left(E_{\mathrm{a}}\right)$ determined using the Arrhenius equation confirms that the biosorption involved chemical ion-exchange. Kinetic studies show that the MB removal followed pseudo-second-order rate equation, while thermodynamic studies suggest that the biosorption process was spontaneous and exothermic. Finally, it can be concluded that HFs, a common and easily available waste biomaterial can be used as an economical biosorbent for the removal of MB from aqueous solutions.

Open Access This article is distributed under the terms of the Creative Commons Attribution License which permits any use, distribution and reproduction in any medium, provided the original author(s) and the source are credited.

\section{References}

Agrahari S, Wadhwa N (2010) Degradation of chicken feather a poultry waste product by keratinolytic bacteria isolated from dumping site at Ghazipur Poultry Processing plant. Int J Poult Sci 9:482-489

Aguayo-Villarreal A, Bonilla-Petriciolet A, Hernandez-Montoya V, Montes-Moran MA, Reynel-Avila HE (2011) Batch and column studies of $\mathrm{Zn}^{2+}$ removal from aqueous solution using chicken feathers as sorbents. Chem Eng J 167:67-76

Ahmad R (2009) Studies on adsorption of crystal violet dye from aqueous solution onto coniferous pinus bark powder (CPBP). J Hazard Mater 171:767-773

Ahmad A, Rafatullah M, Sulaiman O, Ibrahim MH, Hashim R (2009) Scavenging behaviour of meranti sawdust in the removal of methylene blue from aqueous solution. J Hazard Mater 170:357-365

Aksakal O, Ucun H (2010) Equilibrium, kinetic and thermodynamic studies of the adsorption of textile dye (Reactive Red 195) onto pinus sylvestris L. J Hazard Mater 181:666-672

ALzaydien AS (2009) Adsorption of methylene blue from aqueous solution onto a low-cost natural Jordanian Tripoli. Am J Environ Sci 5:197-208

Annadurai G, Juang R, Lee D (2002) Use of cellulose-based wastes for adsorption of dyes from aqueous solutions. J Hazard Mater 92:263-274

Banat F, Al-Asheh S, Al-Ahmad R, Bni-Khalid F (2007) Bench-scale and packed bed sorption of methylene blue using treated olive pomace and charcoal. Bioresour Technol 98:3017-3025

Bapat P, Nandy SK, Wangikar P, Venkatesh KV (2006) Quantification of metabolically active biomass using methylene blue dye reduction test (MBRT): measurement of CFU in about $200 \mathrm{~s}$. J Microbiol Methods 65:107-116 
Bhattacharyya KG, Sharma A (2005) Kinetics and thermodynamics of methylene blue adsorption on neem (Azadirachta indica) leaf powder. Dyes Pigments 65:51-59

Blanchard G, Maunaye M, Martin G (1984) Removal of heavy metals from waters by means of natural zeolites. Water Res 18:1501-1507

Bulut Y, Aydin HA (2006) Kinetics and thermodynamics study of methylene blue adsorption on wheat shells. Desalination 194:259-267

Chakraborty S, Chowdhury S, Saha PD (2011) Adsorption of crystal violet from aqueous solution onto $\mathrm{NaOH}$-modified rice husk. Carbohydr Polym 84:1533-1541

Chowdhury S, Saha P (2010a) Sea shell powder as a new adsorbent to remove Basic Green 4 (Malachite Green) from aqueous solutions: equilibrium, kinetic and thermodynamic studies. Chem Eng J 164:168-177

Chowdhury S, Saha P (2010b) Pseudo-second-order kinetic model for biosorption of methylene blue onto tamarind fruit shell: comparison of linear and non-linear methods. Biorem J 14:196-207

Chowdhury S, Mishra R, Saha P, Kushwaha P (2011a) Adsorption thermodynamics, kinetics and isosteric heat of adsorption of malachite green onto chemically modified rice husk. Desalination 265:159-168

Chowdhury S, Chakraborty S, Saha P (2011b) Biosorption of Basic Green 4 from aqueous solution by Ananas comosus (pineapple) leaf powder. Colloids Surf B 84:520-527

Chowdhury S, Mishra R, Kushwaha P, Das P (2011c) Optimum sorption isotherm by linear and non-linear methods for safranin onto alkali treated rice husk. Biorem J 15:77-89

Crini G, Peindy HN, Gimbert F, Robert C (2007) Removal of C. I. Basic Green 4 (Malachite Green) from aqueous solution by adsorption using cyclodextrin-based adsorbent. Sep Purif Technol 53:97-110

de Oliveira Brito SM, Andrade HMC, Soares LF, de Azevedo RP (2010) Brazil nut shells as a new biosorbent to remove methylene blue and indigo carmine from aqueous solutions. J Hazard Mater 174:84-92

Demir H, Top A, Balkose D, Ulku S (2008) Dye adsorption behavior of Luffa cylindrica fibers. J Hazard Mater 153:389-394

Dogar C, Gürses A, Acıkyıldız M, Özkan E (2010) Thermodynamics and kinetic studies of biosorption of a basic dye from aqueous solution using green algae Ulothrix sp. Colloids Surf B 76:279-285

Dubinin MM, Radushkevich LV (1947) The equation of the characteristic curve of the activated charcoal. Proc Acad Sci USSR Phys Chem Sect 55:331-337

Ferrero F (2007) Dye removal by low cost adsorbents: hazelnut shells in comparison with wood sawdust. J Hazard Mater 142:144-152

Foo KY, Hameed BH (2010) Insights into the modeling of adsorption isotherm systems. Chem Eng J 156:2-10

Freundlich HMF (1906) Over the adsorption in solution. J Phys Chem 57:385-470

Garg VK, Amita M, Kumar R, Gupta R (2004) Basic dye (methylene blue) removal from simulated wastewater by adsorption using Indian rosewood sawdust: a timber industry waste. Dyes Pigments 63:243-250

Ghosh D, Bhattacharyya KG (2002) Adsorption of methylene blue on kaolinite. Appl Clay Sci 20:295-300

Gong R, Li M, Yang C, Sun Y, Chen J (2005) Removal of cationic dyes from aqueous solution by adsorption on peanut hull. J Hazard Mater 121:247-250

Hameed BH, Ahmad A (2009) Batch adsorption of methylene blue from aqueous solution by garlic peel, an agricultural waste biomass. J Hazard Mater 164:870-875
Hameed BH, Krishni RR, Sata SA (2009) A novel agricultural waste adsorbent for the removal of cationic dye from aqueous solutions. J Hazard Mater 162:305-311

Han R, Zou W, Yu W, Cheng S, Wang Y, Shi J (2007) Biosorption of methylene blue from aqueous solution by fallen phoenix tree's leaves. J Hazard Mater 141:156-162

Lagergren S (1898) About the theory of so-called adsorption of soluble substances. K. Sven Vetenskapsakad Handl 24:1-39

Langmuir I (1916) The constitution and fundamental properties of solids and liquids. J Am Chem Soc 38:2221-2295

Low KS, Lee CK (1990) The removal of cationic dyes using coconut husk as an absorbent. Pertanika 13:221-228

Mittal A, Kurup L, Mittal J (2007) Freundlich and Langmuir isotherms and kinetics for the removal of Tartrazine from aqueous solutions using hen feathers. J Hazard Mater 146:242248

Nasuha N, Hameed BH, Din ATM (2010) Rejected tea as a potential low-cost adsorbent for the removal of methylene blue. J Hazard Mater 175:126-132

Oladoja NA, Asia IO, Aboluwoye CO, Oladimeji YB, Ashogbon AO (2008) Studies on the sorption of basic dye by rubber (Hevea brasiliensis) seed shell. Turk J Eng Environ Sci 32:143-152

Oliveira LS, Franca AS, Alves TM, Rocha SDF (2008) Evaluation of untreated coffee husks as potential biosorbents for treatment of dye contaminated waters. J Hazard Mater 155:507-512

Ozer D, Dursun G, Ozer A (2007) Methylene blue adsorption from aqueous solution by dehydrated peanut hull. J Hazard Mater 144:171-179

Pavan FA, Lima EC, Dias SLP, Mazzocato AC (2008) Methylene blue biosorption from aqueous solutions by yellow passion fruit waste. J Hazard Mater 150:703-712

Rafatullah M, Sulaiman O, Hashim R, Ahmad A (2010) Adsorption of methylene blue on low-cost adsorbents: a review. J Hazard Mater 177:70-80

Saeed A, Sharif M, Iqbal M (2010) Application potential of grapefruit peel as dye sorbent: Kinetics, equilibrium and mechanism of crystal violet adsorption. J Hazard Mater 179:564-572

Saha P (2009) Study on the removal methylene blue dye using chemically treated rice husk. Asian J Water Environ Pollut $7: 31-41$

Saha P (2010) Assessment on the removal of methylene blue dye using tamarind fruit shell as biosorbent. Water Air Soil Pollut 213:287-299

Saha P, Datta S (2009) Assessment on thermodynamics and kinetics parameters on reduction of methylene blue using fly ash. Desalin Water Treat 12:219-228

Sharma, YC, Uma, Upadhyay SN (2009) Removal of a cationic dye from wastewaters by adsorption on activated carbon developed from coconut coir. Energy Fuels 23:2983-2988

Srinivasan A, Viraraghavan T (2010) Decolorization of dye wastewaters by biosorbents: a review. J Environ Manage 91:19151929

Tan IAW, Ahmad AL, Hameed BH (2008) Adsorption of basic dye using activated carbon prepared from oil palm shell: batch and fixed bed studies. Desalination 225:13-28

Taskin M, Kurbanoglu EB (2011) Evaluation of waste chicken feathers as peptone source for bacterial growth. J Appl Microbiol 111:826-834

Tsai WT, Yang JM, Lai CW, Cheng YH, Lin CC, Yeh CW (2006) Characterization and adsorption properties of eggshells and eggshell membrane. Bioresour Technol 97:488-493

Vadivelan V, Kumar KV (2005) Equilibrium, kinetics, mechanism, and process design for the sorption of methylene blue onto rice husk. J Colloid Interface Sci 286:90-100 
Weng C-H, Lin Y-T, Tzeng T-W (2009) Removal of methylene blue from aqueous solution by adsorption onto pineapple leaf powder. J Hazard Mater 170:417-424

Yao Z, Wang L, Qi J (2009) Biosorption of methylene blue from aqueous solution using a bioenergy forest waste: Xanthoceras sorbifolia seed coat. Clean Soil Air Water 37:642-648
Zaghloul TI, Embaby AM, Elmahdy AR (2011) Biodegradation of chicken feathers waste directed by Bacillus subtilis recombinant cells: scaling up in a laboratory scale fermentor. Bioresour Technol 102:2387-2393 